\title{
VEGETATION OF DECIDUOUS FORESTS IN THE BALKAN PENINSULA*
}

\author{
Andraž Čarni \\ Institute of Biology, Scientific Research Center of the Slovenian Academy of Sciences and Arts, \\ Ljubljana, Slovenia \\ University of Nova Gorica, Nova Gorica, Slovenia \\ Macedonian Academy of Sciences and Arts, Skopje, Republic of Macedonia
}

carni@zrc-sazu.si

\begin{abstract}
The article provides an overview of deciduous forests of the Balkan Peninsula. It presents riverine, floodplain and moor forests, dominated by Alnus incana, A. glutinosa, Fraxinus excelsior, F. angustifolia, Quercus robur, Salix alba, Ulmus laevis, U. minor; acidophilous forests dominated by Betula pendula, Castanea sativa, Fagus sylvatica, Quercus petraea; thermophilous forests dominated by Carpinus orientalis, Ostrya carpinifolia, Quercus cerris, $Q$. farainetto, Q. petraea, Q. pubescens and mesophilous forests dominated by Carpinus betulus, Fagus sylvatica, F. orientalis, Fraxinus excelsior, Tilia argentea, T. cordata, T. platyphyllos, Ulmus glabra. At the same time, forests were classified into the synsystematic framework of the standard Central European system to the level of an alliance.
\end{abstract}

Keywords: Balkan; forest; vegetation; classification

Nomenclatural source: Euro+Med Plantbase (http://ww2.bgbm.org/EuroPlusMed)

\section{INTRODUCTION}

Research into vegetation in southeastern Europe has a long tradition. The first fundamental works about vegetation in the region were based on the so-called physiognomic-ecological approach and originate from the beginning of the $20^{\text {th }}$ century, when Gabriel Beck-Mannagetta published his work Vegetationsverhältnisse der illyrischen Länder [1] and Lujo Adamović his work Vegetationsverhälnisse der Balkanländer [2]. At the beginning of the $20^{\text {th }}$ century, a new science - phytosociology - was established [3]. Soon after its beginning in Europe, research in the Balkans began according to this method [4] and the new science was widely accepted among researchers in the region. Our presentation is based on the standard Braun-Blanquet method and its hierarchy; so we group associations (ending -etum) into alliances (ending -ion), alliances into orders (ending -etalia) and those into classes (ending -etea) [5]. As a result of long and intensive research in the region, during recent years some important surveys of forest vegetation of some parts of the region has appeared, e.g. Slovenia [6], Croatia [7], Serbia [8], Kosovo [9], Bulgaria [10] and Greece [11, 12]. These and many other studies have enabled us to make an overview of forest vegetation of the region.

The large number of publications all over Europe encouraged a group of authors guided by Ladislav Mucina to start preparation of an overview over all vegetation types of the whole of Europe to the alliance level, from the Canary Islands to the Urals and from Cyprus to Greenland [13]. It is based on a list of vegetation classes [14] and on a preliminary overview of alliances [15]. During the procedure, literature sources all over Europe have been checked and many nomenclature corrections and some revisions of individual syntaxa have been published, for instance $[16,17]$.

This paper is intended to give an overview of deciduous forests of the region on the alliance lev-

*The paper was presented as an inaugural lecture by the author on the occasion of his election to be a member of the Macedonian Academy of Sciences and Arts on $5^{\text {th }}$ May 2016 in Skopje. 
el, to synchronize regional classification schemes with the European one [13], to show the present state of knowledge and to detect some problems. At the same time, it will facilitate integration of the vegetation of deciduous forests into the wider European framework, into various overviews of forest vegetation, red lists and similar [18].

\section{DESCRIPTION OF AREA}

The Balkan Peninsula has a large altitudinal diversity, since a great part of the territory has an altitude of over $1000 \mathrm{~m}$, and provides a large altitudinal range through a relatively small latitudinal range of $10^{\circ}$. At the same time, the Balkan Peninsula is a highly complex region in terms of geology, climate and vegetation. The diverse geology is the most important factor contributing to the diversity of flora: there are crystalline massifs, such as Rhodopes and new fold mountains, such as the Dinaric Alps or the Shar-Pindos mountain range, composed of limestone [19].

The climatic conditions are parallel its geographical position, relief and extensive coastline (Figure 1). Belgrade in the northern part, which is cut off from the influence of the Mediterranean and lies open to central and eastern Europe, is dominated by a continental climate with maximum of precipitation in May-June. Ljubljana has a mountain climatic regime, with two peaks of precipitation, in spring and autumn. Ohrid in the south is also located in mountains but is influenced by a Mediterranean climate and an autumn peak can be observed. Ljubljana has more precipitation but Ohrid and Belgrade have almost the same amount, although Belgrade has precipitation during the vegetation season, that is more propitious for flora and vegetation, and also for agriculture, whereas in Ohrid the majority of precipitation falls in the part of the year in which the vegetation cannot use it.

\section{OBJECT}

The potential vegetation of the major part of the Balkan Peninsula is represented by deciduous broadleaved forest. Broadleaved deciduous forests appear in the areas with relatively moist summers and mild winters. Forests can be divided into two subgroups: mesic and warm temperate forests. Mesic temperate forests appear in the humid sub Atlantic climate and are dominated by mesophilous deciduous tree species, such as Fagus sylvatica, Carpinus betulus, Acer pseudoplanatus, Alnus glutinosa etc. Warm deciduous forests appear in areas under the influence of continental and Mediterrane- an climates, in which summer drought is more pronounced. These forests are dominated by various species from the genus Quercus, Ostyra carpinifolia, Carpinus orientalis etc. [20].
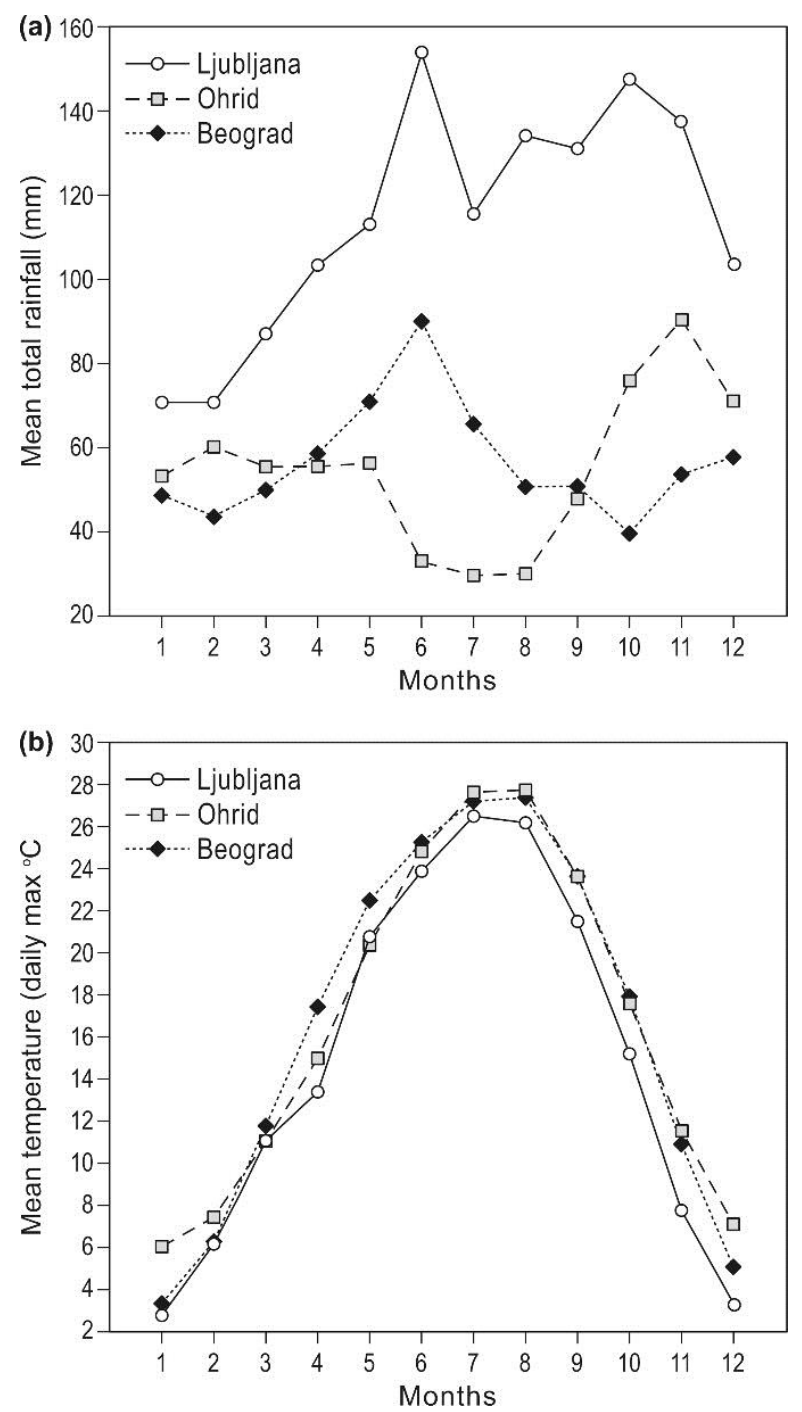

Figure 1. Mean total rainfall (a) and mean monthly temperatures (b) in the research area. Climatological information for Ljubljana, Ohrid and Belgrade (World Meteorological Organization data, http://www.wmo.int/pages/index_en.html)

\section{CONTACT FORESTS}

In the case of increased cooling or increasing drought, deciduous forests are in contact with coniferous ones. In cold and humid areas, they are in contact with forests dominated by Picea abies and Abies $a l b a$, as well as Larix decidua. In drier areas, two relict coniferous forests appear, Pinus peuce and $P i$ nus heldreichii, and a hybrid between Abies alba and Abies cephalonica Abies borisii-regis forests. Deciduous forest can also be in contact with Pinus syl- 
vestris and Pinus nigra but these two species do not form zonal forests and appear locally in extreme conditions (e.g. extreme drought or acidity) [21-26].

In areas under the influence of the Mediterranean climate, deciduous forests are in contact with evergreen broadleaved forests. A warm climate with mild winters is characteristic of Mediterranean evergreen vegetation dominated by evergreen tree species, such as Quercus ilex, Q. coccifera, and their substitutes, maquis, garrigues. In some cases, they can also come in contact with coniferous forests of Mediterranean mountains [27-29].

\section{HISTORY}

One of the main factors determining the present vegetation is the development of vegetation during and after the ice ages (Figure 2). This area was covered with no or relatively little ice during the last glaciation and the assumed July temperature was only $5^{\circ}$ cooler than present, which probably provided a suitable environment for the survival of temperate tree taxa. Since most water was bound in ice, the sea level was lower and half of the Adriatic Sea was part of the mainland. From the point of view of phytogeography, the land connection to the Apennines is also important and caused the two peninsulas to share some common or closely related taxa and vegetation types. The area of common (syn)taxa could also be called the Apennine-Dinaric window in phytogeography [30-32].

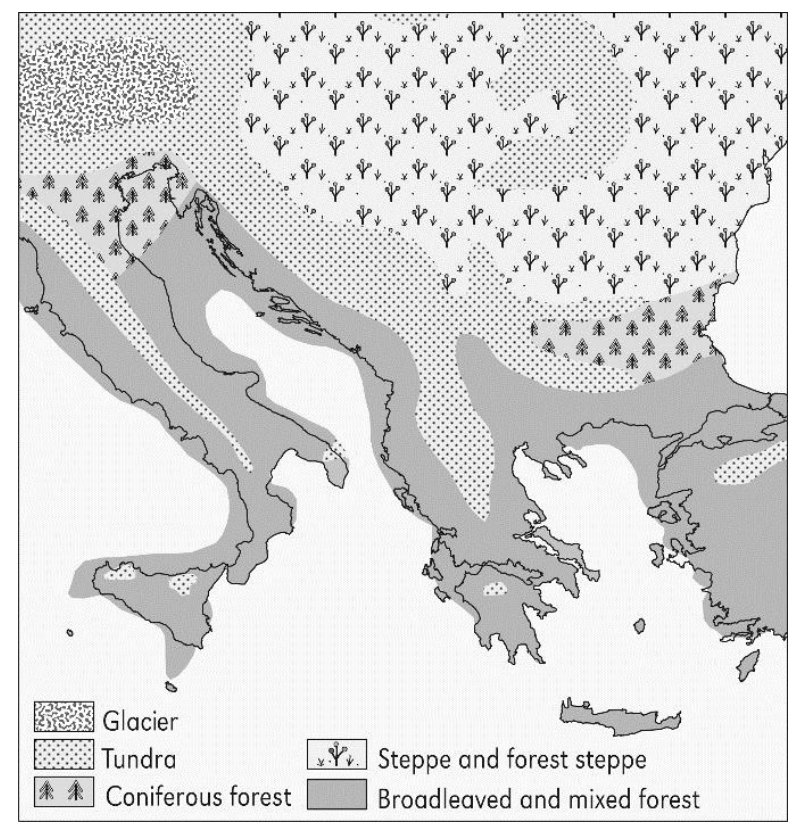

Figure 2. Vegetation cover of the Balkan during ice age (Würm) (after [33]).
The area was covered by forest, tundra and steppe and it was one of the refugial areas for tree species in Europe. Even now, the highest diversity of tree species in Europe is found in the southern part of Macedonia, where there are over 130 woody species [34].

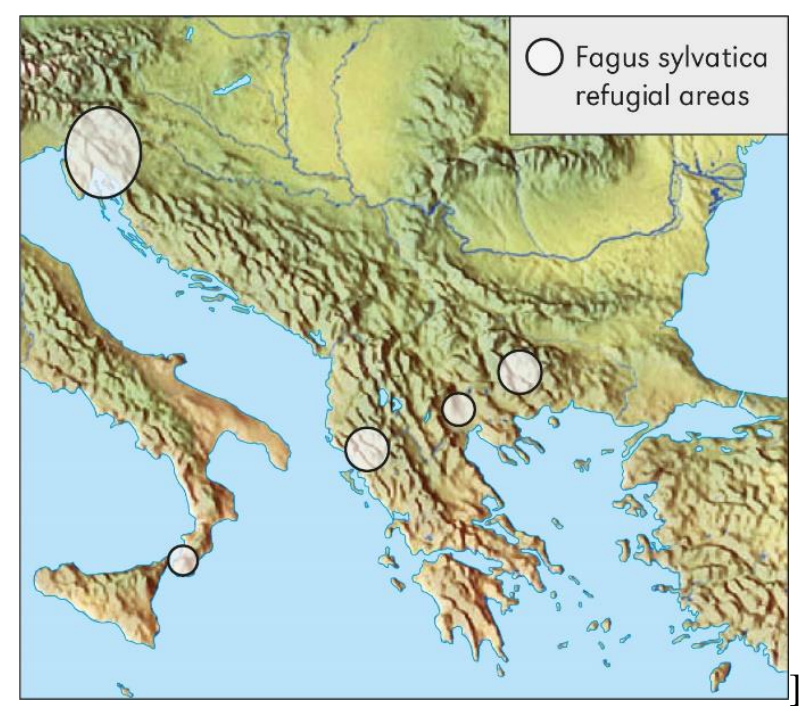

Figure 3. Refugial areas of beech (after [35]).

There were macro refugia of mesophilous forest in the northwestern part of the region (Figure 3 ). The major refugia of beech forests were in the northwestern part of the Balkans and beech spread out from these refugia practically all over Europe. These refugia were at an altitude between 600 and $800 \mathrm{~m}$, since in the lowlands it was too dry, and at higher altitudes it was too cold. So called Illyricoid flora (e.g. Lamium orvala, Omphalodes verna etc.) (sensu Trinajstić) also survived here, i. e. mesophilous endemic species that survived in these mesophilous forests. A distinction has thus been made between Illyric species - endemics surviving on extreme habitats and Illyrioid species - mesophilous endemics $[35,36]$.

The situation was different with thermophilous forests; their primary refugia were in the south but in warmer periods they expanded towards the north and could sometimes survive colder periods in those areas, in so called secondary refugia (Fig. 4). Evidence exists that in the southern Balkans there were macro refugia of warm temperate forests and also cryptic (smaller) refugia of mesic temperate forests. The macro refugia were more species rich but cryptic refugia also had their floristic individuality $[20,37,38]$.

Most research of the history of forests has been done by people from outside the region and 
the focus has been on the location of refugia and the time needed for temperate trees to migrate from these areas to northern Europe [39]. The vegetation history of the Balkans has much greater significance for the development of forests than this. If the temperate trees were present in the region during the last glacial period, then it is an important region in which we can study them in terms of understanding forest development without the arrival of any immigrant taxa. If migration was not a significant factor in the postglacial vegetation succession of the region, other factors need to be considered to explain the type and rates of postglacial vegetation change. This can include external forces such as climate change and internal factors such as soil development and forest dynamics [40, 41].

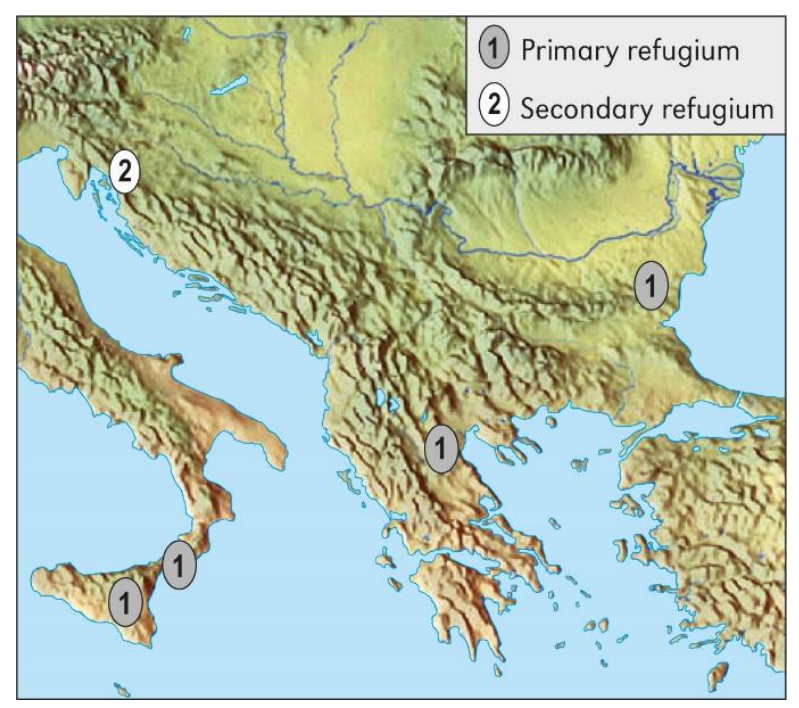

Figure 4. Refugial areas of oak species (after [37]).

The species that were present in the region could adapt to climatic and other conditions and could even genetically change in a fairly short time during the Holocene. Here there can be found, for instance, two subspecies of the species Cistus incanus: $C$. incanus subsp. incanus and $C$. incanus subsp. creticus. These subspecies can be explained by a process of adaptive radiation within Cistus incanus agg. Specimens found in the continental parts of the Balkans have larger leaves, a straight leaf margin and do not have glandules, whereas specimens in the coastal areas have glandules and undulated leaf margins. These differences are treated taxonomically on the level of subspecies; specimens in the continent are treated as the typical subspecies, whereas those in the coastal regions as the subspecies creticus. It should still be tested whether these differences are genetically fixed; what would happen if plants from the coastal region were planted in continental conditions and vice-versa [42, 43].

\section{BIOGEOGRAPHICAL DIVISION OF THE REGION}

The following biogeographical regions can be found in the area: the Mediterranean, which is linked to the coastal area; the mountain area is classified within the alpine region, while the majority of the area is connected to the continental region and there is a small part that can be attached to the Pannonian region; there is also a Black Sea region along the Black Sea coast. (European Environmental Agency: www.eea.eu.int).

This is the commonly accepted solution of the biogeographical division. However, other divisions can also be found, including that of Oberdorfer, who drew a distinction between the Mediterranean area and the Eurosibirian region in the northern part of the Balkans. This distinction is based on two factors. Evergreen vegetation can be found only in the southernmost part of Greece and there is quite a large area of submediterranean thermophilous deciduous forest there, unlike the situation in the western Mediterranean. The other factor is that the transition between evergreen and deciduous vegetation is fairly continuous; there is maquis consisting only of evergreen species, then pseudomaquis consisting of a mixture of evergreen species and deciduous species and šibljak consisting only of deciduous species. On the other hand, the division between mesophilous deciduous and thermophilous deciduous forest is fairly obvious $[27,45]$.

\section{OVERVIEW OF FORESTS}

\section{Riverine, floodplain and moor forest}

These forests appear in areas that are under the influence of a watercourse or underground water. The boundary of these habitats in floodplains is the line that is reached by the highest floods. The time when the highest water level is attained depends on the water regime; rivers that have their source in the mountains have the highest level during late spring, when the snow melts, while others have their maximum during high precipitation, and floods can happen unexpectedly due to sudden high precipitation, often causing destruction. When the water level is low, these forests can often be dry. Species need to be able to adapt to floods, to survive the submerged period, to have flexible branches not be broken by a water course etc. and also to survive the lack of humidity during low water lev- 
els. On the other hand, these habitats are very rich in nutrients, which the water flow brings and deposits and this makes the habitats one of the richest in the landscape. At the same time, these deposits can be carried out by the next floods and so the best position for growth is near the edge of average floods, where the fine deposits are left and are not too often carried off. In these stands, the development of a soil profile can already be found. The river brings deposits and gravel with flow, which are deposited in its bed. The river climbs above the landscape in this way and moor vegetation can be found in the hinterland. These moor forests are often dominated by Alnus glutinosa, since this species well supports the high ground water over the whole year. These stands can be occasionally flooded. This vegetation seems to be to a large extent azonal and does not show a special geographic pattern. In lowlands, such stands are often in contact with zonal oakhornbeam forest in the north and with thermophilous deciduous forest in the south; pine forests can sometimes be found on old gravel deposits [46-50].

The majority of these forests are classified into Alno-Populetea albae, which encompass floodplain and riverine forests of the Eurosibirian and Mediterranean regions. The class is divided into two orders, which reflect macroclimatic conditions: Populetalia albae in the Mediterranean region and Alno-Fraxinetalia in the temperate region. Within the Mediterranean part, Platanus dominated communities can be distinguished, classified as Platanion orientalis and Lauro nobilis-Fraxinion angustifoliae encompassing other floodplain and riparian forests [51]. Forests of the temperate order AlnoFraxinetalia can be divided into two alliances; $A l$ nion incanae encompassing forests appearing along the upper stream of rivers and dominated to a large extent by alders (Alnus glutinosa, A. incana) and Alno-Quercion, which appear downstream and are dominated by Fraxinus, Ulmus and Quercus. Alnion incanae is in close contact with oak-hornbeam forests and, in some cases, these forests share many common species. Some authors do not recognize the individuality of the two alliances: Alnion incanae and Alno-Quercion [7, 52]. Riparian willow forests, appearing mainly on lowland alluvia, are classified within Salicetea purpureae, Salicetalia purpuraea and Salicion albae. Mesotrophic forests appearing in waterlogged sites are classified into Alnetea glutinosae, Alnetalia glutionsae and Alnion glutinosae [46-52].

\section{Acidophilous forests}

These forests appear on less productive soils, where more demanding species such as hornbeam, maple and others cannot thrive. Deciduous acidophilous forests are dominated by Fagus sylvatica, Quercus petraea and Betula pendula. It has been established that Quercus robur is rarely a dominant in such forests in the region. Fagus sylvatica dominated forests are classified into the group of beech forests (Carpino-Fagetea). Oak and birch forests are also classified into two different classes (see further). Mesic-acidophilous oak dominated forests appear only in the western part of the region, while in the eastern part acidothermophilous oak forests belong to the group of thermophilous deciduous forests and are classified within the class Quercetea pubescentis. Birch forests can be found all over the region. These forests are to a large extent the result of human activities over centuries. With the abandonment of exploitation, succession is liberated and they can convert to mesic forests $[7,8,53,54]$.

Castanea sativa dominated forests need further research. Castanea sativa originates from the Quercion frainetto zone and is probably non-native in the northwestern part of the Balkans. It grows not only on acidic soils but can also appear on other substrata, so these forests can be classified into various groups: acidophilous, mesophilous, thermophilous deciduous and ravine forests [12, 55-59].

Acidophilous oak dominated forests are classified into the group of acidophilous oak and birchoak forests on nutrient poor soils, Quercetea roboris-petraeae and Quercetalia roboris. Two alliances appear; one from temperate regions, Agrostio-Quercion petraeae and the other from submediterranean regions, Castaneo-Quercion. The division between these two alliances in the area should be reconsidered in the future. In recent years, proposals have been made to separate birch forests from oak forests on the class level and to classify them within the group of hemiboral pine and birchpine herb rich open forests on fertile soils and relict birch-poplar forest Brachypodio pinnati-Betuletea pendulae and further into relict extrazonal temperate deciduous birch-poplar woods on mineral soil Fragario vescae-Populetalia tremulae and Fragario vescae-Populion tremulae [17, 60, 61].

\section{Thermophilous deciduous forests}

The most widespread forests of the region are thermophilous deciduous forests. They can be divided into two larger groups. (1) The first is dominated by various oak species. They form zonal forests in the southern-eastern part of the region and extrazonal forests on loess substratum on the edges of the Pannonian basin, as well as forests on south- 
ern slopes on carbonate bedrock in the northwestern part. Thermophilous-acidophilous oak forests appearing in the central and eastern part of the region are also attached to this group. (2) The second group is dominated by Ostrya carpinifoila, Quercus pubescens and Carpinus orientalis. Such vegetation can be found along the coast in the submediterranean area, on steep slopes with shallow soils on carbonate mountain chains that separate the coast and the continent, such as the Dinaric Alps or SharPindos mountain range and on dry calcareous sites in the hinterland [62-65].

These forests are classified within Quercetea pubescentis and Quercetalia pubescenti-petraeae, a group of forests that are dominated by various oak species ( $Q$. pubescens, $Q$. cerris, $Q$. petraea, $Q$. frainetto, etc.), oriental hornbeam (Carpinus orientalis), hop hornbeam (Ostrya carpinifolia), as well as Mediterranean relict fir species (A. cephalonica). This vegetation is fairly diverse and can be divided into several subunits. Within this framework can be distinguished submediterranean forests dominated by Quercus pubescens and Carpinus orientalis Carpinion orientalis, meso-thermophilous supraMediterranean and relic forests dominated by Ostyra carpinifolia Fraxino orni-Ostryion and continental thermophilous forests dominated by Carpinus orientalis Syringo-Carpinion orientalis, thermophilous continental forests of deep, neutral to slightly acidic soils dominated by Quercus frainetto and Quercus cerris Quercion confertae and those under maritime influence Melitto albidae-Quercion, dry acido-thermophilous (sub)montane continental forests dominated by Quercus petraeae and Quercus cerris Quercion petraeo-cerridis, acido-thermophilous northern-dinaric and southern-pannonian Quercus petraea dominated forests Quercion pubescenti-petraeae, and thermophilous oak forests on deep soils in the forest-steppe zone in the northern part of the region Aceri tatarici-Quercion [12, $66,67]$.

\section{Ravine forests}

Broadleaved ravine forests grow especially on restricted sites with specific soil conditions. They occur on slopes, at the foot of slopes, in sinkholes, gorges and hollows with colluvial, skeletal and primarily unstable soils, which allow broadleaved trees such as Acer platanoides, Acer pseudoplantus, Fraxinus excelsior, Tilia sp. div. to settle and replace competitively stronger species, mainly Fagus sylvatica. These species are called noble trees, because their litter decays quickly and ameliorates the soils, and so many high stalk plants can be found in these forests, such as Lunaria rediviva, Urtica dioica and many others. Within the area of the southern Alps and southeastern Europe, these forests can be classified within two large groups: thermophilous scree and ravine forests dominated by Tilia sp. div. and Ostrya carpinifolia and mesophilous scree and ravine forests dominated by Acer pseudoplatanus, Fraxinus excelsior and Ulmus glabra [68].

These forests are classified within mesic deciduous and mixed forests Carpino-Fagetea, as well as scree and ravine forests Aceretalia pseudoplatani. In the region, this group can be divided into mesophilous ash-maple forests Fraxino-Acerion and thermophilous lime-hop hornbeam forests Ostryo carpinifoliae-Tilion platyphylli $[17,69]$.

\section{Oak-hornbeam forests}

Oak-hornbeam forests appear as zonal vegetation of the plains and hilly region of the northwestern part of the Balkan Peninsula, whereas in the southeastern part hornbeam forests can be found only extrazonally in valleys, along water courses and other habitats that offer humidity and mesic site conditions. In the southeastern part of the region, oak-hornbeam forests are replaced by thermophilous deciduous forests as zonal lowland forests. In the northwestern part of the region, oakhornbeam forests are in contact with beech forests, which form the submontane vegetation belt. In the lowlands, oak and hornbeam outcompete beech because they better support summer drought and spring frosts. In the transitional zone, beech forests are often converted into oak-hornbeam coppiced forests. In natural stands, oak can be found in the upper and hornbeam in the lower tree layer. However, this vertical zonation in a stand can often be changed by forest management; pure hornbeam or oak forests can be found. Oak-hornbeam forests also appear on more humid sites. Since hornbeam is more susceptible to underground and surface water, it gradually disappears from stands and those forests are classified into floodplain forests. [57, 70-72]

Oak-hornbeam forests are classified within the class of mesic deciduous and mixed forests Carpino-Fagetea; specifically they belong to oakhornbeam and mesic oak forests on deep nutrient rich soils Carpinetalia betuli. Oak-hornbeam forests of the Balkans are classified into ErythronioCarpinion betuli; within this framework two suballiances can be distinguished, as moesian oakhornbeam forests Aceri tartarici-Carpinenion and illyric oak-hornbeam forests Lonicero caprifolii- 
Carpinenion. Hornbeam forests in the southeastern part of the Balkans can be classified into CastaneoCarpinion orientalis, which has its center of distribution in northern Anatolia [49, 73].

\section{Beech forests}

Beech forests cover a large proportion of the European forest area. It has to be considered that beech gained the dominant role in European forests in the subatlantic period about 2500 years ago and in about 30 generations has formed well established forest communities. The population originating from the northwestern Balkans is the most vital, since it has settled nearly the whole continent. Beech can be found in intermediate sites that are not too wet and not too dry, not too nutrient rich nor too poor, not too warm or too cold. It has its optimum habitats in the montane belt, where it builds monodominant stands that are sometimes mixed with fir (Abies alba, A. borisii-regis). In the northwestern part of the region, beech forests occupy various sites and have a wide altitudinal range, while in the southeastern part of the region and on the edge of the Pannonian plain, in their border range, they can only be found in humid mountain areas. [11, 35, 74, 75].

During elaboration of beech forests, we treated only the taxa Fagus sylvatica subsp. sylvatica and Fagus sylvatica subsp. orientalis. The intermediate taxon Fagus sylvatica subsp. moesiaca was attached to Fagus sylvatica subsp. sylvatica [75].

Classification of beech forests has been taking place for nearly a century and a common consensus could not be reached. Three main gradients can be observed with beech forests: soil $\mathrm{pH}$, temperature and geography, of which the last includes macroclimatic gradients and, at the same time, also a history of the spread of beech forests. A consensus has been achieved about acidophilous beech forests and beech forests on acid soils in temperate Europe are classified within a separate group. However, basiphilous beech forests have given rise to major discussion among researchers. It is not obvious which factor is more important, temperature or geography. If temperature is more important, units would be ecologically defined and subunits geographically, and viceversa. A consensus has recently been achieved that both approaches can be considered equally relevant. With the European classification system, it has been accepted that the mostly well-defined alliances should be retained. $[13,76]$
Acidophilous beech forests, illyric beech forests, moesian beech forests and south Balkan beech forests form individual groups in the region. All beech forests from Europe have been classified into the class of mesic deciduous and mixed forests Carpino-Fagetea. Acidophilous beech forests are classified into Luzulo-Fagetalia sylvaticae and Luzulo-Fagion. Basiphilous beech forests are classified into Fagetalia sylvaticae. These forests from the illyric floristic province are further classified into Aremonio-Fagion. Moesian beech forests are not well defined floristically and it was decided to attach them partly to Central European beech forests Fagion sylvaticae and partly to south Balkan beech forests. South Balkan beech forests are grouped into Geranio striati-Fagion. The latter group also comprises some acidophilous communities. [11, 13, 76]

\section{Oriental beech forests}

Fagus orientalis appears in Europe in the extreme southeastern part, in Turkey, Bulgaria and Greece. The distribution center of these forests is in the Euxinian province, which is situated in the central part of the Turkish Black Sea region. On the basis of analysis, these forests were divided into seven groups (alliances). Only two groups can be found in Europe: submontane and ravine beech forests. Within the European classification system, only one alliance is recognized, containing all oriental beech forests of Europe. Oriental beech forests are classified within the class of mesic deciduous and mixed forests Carpino-Fagetea and within oriental beech forests Rhododendro pontici-Fagetalia orientalis. Oriental beech forests appearing in Europe are classified within Fagion orientalis [13, 76, 77].

\section{CONCLUSIONS}

The presentation provides a brief overview of deciduous forests of the Balkan Peninsula on the alliance level. An attempt is made to put all forests of the region into a logical system that is integral within the region and corresponds to the European classification scheme. However, other classification concepts still exist, each with its own shortcomings and inconsistencies, and much effort will be needed to attain the optimal solution.

Acknowledgement. I owe thanks to Academician Vlado Matevski, who stimulated the preparation of this contribution. I also thank Iztok Sajko, who kindly prepared the illustrations. The preparation of the article was funded by the Slovenian Research Agency (P1-0236). 


\section{Appendix}

Synsystematic scheme (after [13]):

Alno glutinosae-Populetea albae P. Fukarek et Fabijanić 1968

Populetalia albae Br.-Bl. ex Tchou 1949 nom. conserv. propos.

Platanion orientalis I. Kárpáti et V. Kárpáti 1961

Lauro nobilis-Fraxinion angustifoliae I. Kárpáti et V. Kárpáti 1961

Alno-Fraxinetalia excelsioris Passarge 1968

Alnion incanae Pawłowski et al. 1928

Alno-Quercion roboris Horvat 1950

Salicetea purpureae Moor 1958

Salicetalia purpureae Moor 1958

Salicion albae Soó 1951

Alnetea glutinosae Br.-Bl. et Tx. ex Westhoff et al. 1946

Alnetalia glutinosae Tx. 1937

Alnion glutinosae Malcuit 1929

Quercetea robori-petraeae Br.-Bl. et Tx. ex Oberd. 1957

Quercetalia roboris Tx. 1931

Agrostio-Quercion petraeae Scamoni et Passarge 1959

Castaneo-Quercion petraeae Soó 1964

Brachypodio pinnati-Betuletea pendulae Ermakov et al. 1991

Fragario vescae-Populetalia tremulae Willner et Mucina in Willner et al. 2016

Fragario vescae-Populion tremulae Willner et Mucina ined.

Quercetea pubescentis Doing-Kraft ex Scamoni et Passarge 1959

Quercetalia pubescenti-petraeae Klika 1933

Carpinion orientalis Horvat 1958

Fraxino orni-Ostryion Tomažič 1940

Syringo-Carpinion orientalis Jakucs (1959) 1960

Quercion confertae Horvat 1958

Melitto albidae-Quercion Barbero et Quézel 1976

Quercion petraeo-cerridis Lakušić et B. Jovanović in B. Jovanović et al. ex Čarni et Mucina 2015

Quercion pubescenti-petraeae Br.-Bl. 1932 nom. mut.

Aceri tatarici-Quercion Zólyomi 1957

Carpino-Fagetea sylvaticae Jakucs ex Passarge 1968

Aceretalia pseudoplatani Moor 1976 nom. conserv. propos.

Fraxino excelsioris-Acerion pseudoplatani P. Fukarek 1969

Ostryo carpinifoliae-Tilion platyphylli (Košir et al. 2008) Čarni in Willner et al. 2016

Carpinetalia betuli P. Fukarek 1968

Erythronio-Carpinion (Horvat 1958) Marinček in Wallnöfer et al. 1993

Castaneo sativae-Carpinion orientalis Quézel, Barbero et Akman ex Quézel et al. 1993

Luzulo-Fagetalia sylvaticae Scamoni et Passarge 1959

Luzulo-Fagion sylvaticae Lohmeyer et Tx. in Tx. 1954

Fagetalia sylvaticae Pawłowski 1928

Aremonio-Fagion (Horvat 1950) Borhidi in Török et al. 1989

Fagion sylvaticae Luquet 1926

Geranio striati-Fagion Gentile 1970

Rhododendro pontici-Fagetalia orientalis Passarge 1981

Fagion orientalis Soó 1964

\section{REFERENCES}

[1] Beck-Mannagetta, G., Die Vegetationsverhältnisse der illyrischen Länder, begreifend Südkroatien, die Quarnero-Inseln, Dalmatien, Bosnien und die
Hercegovina, Montenegro, Nordalbanien, den Sandžak Novipazar und Serbien. Verlag von Wilhelm Engelmann, Leipzig, 1901.

[2] Adamović, L., Die Vegetationsverhältnisse der Balkanländer (Mösische Länder): umfassend 
Serbien, Altserbien, Bulgarien, Ostrumelien, Nordthrakien und Nordmazedonien. Verlag von Wilhelm Engelmann, Leipzig, 1909.

[3] Blasi, C., Biondi, E., \& Izco, J., 100 years of plant sociology: A celebration. Plant Biosystems 145 (2010), pp. 1-3.

[4] Pevalek, I., Geobotanička i algološka istraživanja cretova u Hrvatskoj i Sloveniji. Radovi Jugoslovenske akademije znanosti i umjetnosti 230 (1925), pp. 29-117.

[5] Braun-Blanquet, J., Pflanzensoziologie, Grundzüge der Vegetationskunde. Springer Verlag, Wien, 1964.

[6] Šilc, U., \& Čarni, A., Conspectus of vegetation syntaxa in Slovenia. Hacquetia 11 (2012), pp. 113-164.

[7] Vukelić, J., Šumska vegetacija Hrvatske. Šumarski fakultet, Sveučilište u Zagrebu, DZZP, Zagreb, 2012.

[8] Tomić, Z., \& Rakonjac, L., Šumske fitocenoze Srbije: Priručnik za šumare, ekologe $i$ biologe. Univerzitet Singidunum, Fakultet za primenjenu ekologiju Futura i Institut za šumarstvo, Beograd, 2013.

[9] Rexhepi, F., The vegetation of Kosova. University of Prishtina, Faculty of Natural Sciences, Pristinë, 2007.

[10] Tzonev, R. T., Dimitrov, M. A., \& Roussakova, V. H., Syntaxa according to the Braun-Blanquet approach in Bulgaria. Phytologia Balcanica 15 (2009), pp. 209-233.

[11] Tsiripidis, I., Bergmeier, E., \& Dimopoulos, P., Geographical and ecological differentiation in Greek Fagus forest vegetation. Journal of Vegetation Science 18 (2007), pp. 743-750.

[12] Bergmeier, E., \& Dimopoulos, P., Identifying plant communities of thermophilous deciduous forest in Greece: Species composition, distribution, ecology and syntaxonomy. Plant Biosystems 142 (2008), pp. 228-254.

[13] L. Mucina, L., Bültmann, H., Dierßen, K., Theurillat, J.-P. Raus, T., Čarni, A., Šumberová, K., Willner, W., Dengler, J., Gavilán García, R., Chytry, M., Hájek, M., Di Pietro, R., Iakushenko D., Pallas, J., Daniëls, F. J. A., Bergmeier, E., Santos Guerra, A., Ermakov, N., Valachovič, M., Schaminée, J. H. J., Lysenko, T., Didukh, Y. P., Pignatti, S., Rodwell, J.S., Capelo, J., Weber, H. E., Solomeshch, A., Dimopoulos, P., Aguiar, C., Hennekens, S. M., \& Tichý, L., Vegetation of Europe: Hierarchical floristic classification system of vascular plant, bryophyte, lichen, and algal communities. Applied Vegetation Science 19 suppl. 1 (2016), pp. 3-264.

[14] Mucina, L., Conspectus of classes of European vegetation. Folia Geobotanica \& Phytotaxonomica 32 (1997), pp. 117-172.
[15] Rodwell, J. S., Schaminée, J. H. J., Mucina, L., Pignatti, S., Dring, J., \& Moss, D., The diversity of European vegetation - An overview of phytosociological alliances and their relationships to EUNIS habitats. National Reference Centre for Agriculture, Nature and Fisheries [report no. ECLNV 2002(054)], Wageningen, 2002.

[16] Čarni, A., \& Mucina, L., Validations and typifications of some South European syntaxa. Hacquetia 14 (2015), pp. 289-299.

[17] Willner, W., Solomeshch, A., Čarni, A., Bergmeier, E., Ermakov, N., \& Mucina, L., Description and validation of some European forest syntaxa - a supplement to the EuroVegChecklist. Hacquetia 15 (2016), pp. 15-25.

[18] Janssen, J. A. M., Rodwell, J. S., Gubbay, S., Haynes, T., Nieto, A., \& Acosta, A., Red list of European habitats project. In Čarni, A., Juvan, N., \& Ribeiro, D., (Eds.), $23^{\text {rd }}$ International Workshop of the European Vegetation Survey, Ljubljana, 812 May 2014 - Book of Abstracts, ZRC Publishing House, Ljubljana, 2014, pp. 220-231.

[19] Griffiths, H. I., Kryštufek, B., \& Reed, J. M. (Eds.). Balkan Biodiversity: Pattern and Process in the European Hotspot. Kluwer Academic, Dordercht, London, 2004.

[20] Čarni, A., Matevski, V., Juvan, N., Kostadinovski, M., Košir, P., Marinšek, A., Paušič, A., \& Šilc, U., Transition along gradient from warm to mesic temperate forests evaluated by GAMM. Journal of Plant Ecology 9 (2016), pp. 410-433.

[21] Em, H., Šumske zajednice četinara u NR Makedoniji. Biološki glasnik 15 (1961), pp. 1-21.

[22] Em, H., Šumite na ela vo Makedonija. Godišen zbornik na Zemjodelsko-šumarski fakultet Univerzitet Kiril i Metodij-Skopje 26 (1974), pp. 41-58.

[23] Zoller, von H., Geissler, P., \& Athanasiadis, N., Beiträge zur Kenntnis der Wälder, Moos- und Flechtenassoziationen in den Gebirgen Nordgriechenlands. Bauchinia 6 (1977), pp. 215-255.

[24] Em, H., O nekim osobenostima borovih šuma Makedonije, II. Šume belog i crnog bora Mariova i Maleša. Prilozi MANU, Oddelenie za prirodnomatematički nauki 2 (1981), pp. 5-16.

[25] Em, H., Na južnoj granici areala smrče, Šuma smrče na Šarplanini u Makedoniji. Prilozi MANU, Oddelenie za prirodno-matematički nauki $\mathbf{5}$ (1986), pp. 11-28.

[26] Juvan, N., Košir, P., Marinšek, A., Paušič, A., \& Čarni, A., Differentiation of the Piceetalia and Athyrio-Piceetalia forests in Slovenia. Tuexenia 33 (2013), pp. 25-48.

[27] Oberdorfer, E., Gliederung und Umgenzung der Mittelmeervegetation auf der Balkanhalbinsel. Bericht über das Geobotanische Forschungsinstitut Rübel in Zürich 1947 (1947), pp. 84-111. 
[28] Bergmeier, E., Wälder und Gebüsche des Niederen Olymp (Káto Olimbos, NO-Thessalien). Ein Beitrag zur systematischen und orographischen Vegetationsgliederung Griechenlands. Phytocoenologia 18 (1990), pp. 161-343.

[29] Matevski, V., Čarni, A., Kostadinovski, M., Marinšek, A., Mucina, L., Paušič, A., \& Šilc, U., Notes on phytosociology of Juniperus excelsa in Macedonia (Southern Balkan Peninsula). Hacquetia 9 (2010), pp. 161-165.

[30] Willis, K., The vegetational history of the Balkans. Quaternary Science Reviews 13 (1994), pp. 769788 .

[31] Willis, K., \& Van Andel, T., Trees or no trees? The environments of central and eastern Europe during the Last Glaciation. Quaternary Science Review 23 (2004), pp. 2369-2387.

[32] Di Pietro, R., Observations on the beech woodlands of the Apennines (peninsular Italy): an intricate biogeographical and syntaxonomical issue. Lazaroa 30 (2010), pp. 89-97.

[33] Anon, Diercke Weltatlas. Westermann, Braunschweig, 2008.

[34] Adams, J., Species Richness. Paterrns in Diversity of Life. Praxis publishing, Chichester, 2009.

[35] Magri, D., Vendramin, G. G., Comps, B., Dupanloup, I., Geburek, T., Gömöry, D., Latałowa, M., Litt, T., Paule, L., Roure, J. M., Tantau, I., Van der Knapp, W. O., Petit, R. J., \& de Beaulieu, J. L., A new scenario for the quaternary history of European beech populations: palaeobotanical evidence and genetic consequences. New Phytologist 171 (2006), pp. 199-221.

[36] Trinajstić, I., A contribution to the phytogeographical classification of the illyrian floral element. Acta Botanica Croatica 51 (1992), pp. 135-142.

[37] Petit, R. J., Brewer, S., Bordács, S., Burg, K., Cheddadi, R., Coart, E., Cottrell, J., Csaikl, U. M., van Dam, B., Deans, J. D., Espinel, S., Fineschi, S., Finkeldey, R., Glaz, I., Goicoechea, P. G., Jensen J. S., König, A. O., Lowe, A. J., Mansen, S. F., Mátyás, G., Munro, R. C., Popescu, F., Slade, D., Tabbener, H., de Vries, S. G. M, Ziegenhagen, B., de Beaulieu, J. L., \& Kremer, A., Identification of refugia and post-glacial colonisation routes of European white oaks based on chloroplast DNA and fossil pollen evidence. Forest Ecology and Management 156 (2002), pp. 49-74.

[38] Birks, H. J. B., \& Willis, K., Alpines, trees, and refugia in Europe. Plant Ecology \& Diversity 1 (2008), pp. 147-160.

[39] Willner, W., Di Pietro, R., \& Bergmeier, E., Phytogeographical evidence for post-glacial dispersal limitation of European beech forest species. Ecography 32 (2009), pp. 1011-1018.
[40] Em, H., Džekov, S., \& Rizovski, R., Za refugijalnata šumska vegetacija vo SR Makedonija. Prilozi MANU, Oddelenie za prirodno-matematički nauki 6 (1985), pp. 5-20.

[41] Šercelj, A., Začetki in razvoj gozdov v Sloveniji. Slovenska akademija znanosti in umetnosti, Ljubljana, 1996.

[42] Čarni, A., Matevski, V., \& Šilc, U., Morphological, chorological and ecological plasticity of Cistus incanus in the southern Balkans. Plant Biosystems 144 (2010), pp. 602-617.

[43] Eriksson, O., Vegetation change and eco-evolutionary dynamics. Journal of Vegetation Science 25 (2014), pp. 1141-1147.

[44] Qian, H., \& Jiang, L., Phylogenetic community ecology: intergration community ecology and evolutionary biology. Journal of Plant Ecology 7 (2014), pp. 97-100.

[45] Adamović, L., Eine bisher nicht unterschiedene Vegetationsformation der Balkanhalbinsel, die Pseudomacchie. Zoologisch-botanische Gesellschaft Wien 56 (1906), pp. 355-360.

[46] Vukelić, J. (Ed.), Poplavne šume u Hrvatskoj. Akademija šumarskih znanosti, Zagreb, 2005.

[47] Čarni, A., Košir, P., Marinček, L., Marinšek, A., Šilc, U., \& Zelnik, I., Komentar $k$ vegetacijski karti gozdnih združb Slovenije v merilu 1 : 50.000. Pomurska akademsko znanstvena unija - PAZU, Murska Sobota, 2008.

[48] Ellenberg, H., Vegetation Ecology of Central Europe. 4th edition. Cambridge University Press, Cambridge, 2009.

[49] Kavgac1, A., Čarni, A., Tecimen, H., \& Özalp, G., Diversity of floodplain forests in the Igneada region (NW Thrace - Turkey). Hacquetia 10 (2011), pp. 73-93.

[50] Košir, P., Čarni, A., Marinšek, A., \& Šilc, U., Floodplain forest communities along the Mura River (NE Slovenia). Acta Botanica Croatica 72 (2013), pp. 71-95.

[51] Kárpati, I., \& Kápati-Nagy, V., Die zönologischen und ökologischen Verhältnisse der Auenwäleder Westbalkans. Mitteilungen der Ostalpin-Dinarischen pflanzensoziologischen Arbeitsgemeinschaft 2 (1961), pp. 101-106.

[52] Douda, J., Boublik, K., Slezák, M., Biurrun, I., Nociar, J., Havrdová, A., Doudová, J., Aćić, S., Brisse, H., Brunet, J., Chytrý, M., Claessens H., Csiky J., Didukh Y., Dimopoulos P., Dullinger S., FitzPatrick, Ú., Guisan, A., Horchler, P. J., Hrivnák, R., Jandt, U., Kącki, Z., Kevey, B., Landuci F., Lecomte, H., Lenoir J., Paal, J., Paternoster, D., Pauli H., Pielech, R., Rodwell J. S., Roelandt, B., Svenning J.-C., Šibík, J., Šilc, U., Škvorc. Ž., Tsiripidis, I., Tzonev R. T., Wohlgemuth T., \& Zimmermann, N. E., Vegetation classification and biogeography of 
European floodplain forests and alder carrs. Applied Vegetation Science 19 (2016), pp. 147163.

[53] Čarni, A., Košir, P., Marinšek, A., Šilc, U., \& Zelnik, I., Changes in structure, floristic composition and chemical soil properties in a succession of birch forests. Periodicum Biologorum 109 (2007), pp. 13-20.

[54] Šilc, U., Čarni, A., Košir, P., Marinšek, A., \& Zelnik, I., Litter-raking forests in SE Slovenia and in Croatia. Hacquetia 7 (2008), pp. 71-88.

[55] Horvat, I., Biljnosociološka istraživanja šuma u Hrvatskoj. Glasnik za šumske pokuse 6 (1938), pp. 127-279.

[56] Wraber, M., Biljnosociološki prikaz kestenovih šuma Bosne i Hercegovine. Godišnjak Biološkog instituta Univerziteta u Sarajevu 9 (1958), pp. 139-182.

[57] Horvat, I., Glavač, V., \& Ellenberg, H. Vegetation Südosteuropas. Gustav Fischer Verlag, Stuttgart, 1974.

[58] Raus, T., Die vegetation Ostthessaliens III. Querco-Fagetea and azonale Gehölzgesellscahften. Botanische Jahrbücher für Systematik, Pflanzengeschichte und Pflanzengeographie 101 (1980), pp. 318-361.

[59] Medak, J., Šuma pitomog kestena sa prasećim zeljem (Aposeri foetidae-Castanetum sativae ass. nova) u Hrvatskoj. Šumarski list - posebni broj 135 (2011), pp. 5-24.

[60] Vukelić, J., Šumske zajednice i staništa hrasta kitnjaka (Quercus petraea Liebl.) u gorju sjeverozapadne Hrvatske. Glasnik za šumske pokuse 27 (1991), pp. 1-82.

[61] Baričević, D., Vukelić, J., Pernar, N., \& Bakšić, D., Acidotermofilne zajednice hrasta kitnjaka $\mathrm{u}$ šumskoj vegetaciji Požeškoga gorja. Glasnik za šumske pokuse, posebno izdanje 5 (2006), pp. 151-165.

[62] Čarni, A., Košir, P., Karadžić, B., Matevski, V., Redžić, S., \& Škvorc, Ž., Thermophilous deciduous forests in Southeastern Europe. Plant Biosystems 143 (2009), pp. 1-13.

[63] Lyubenova, M., Tzonev, R., \& Pachedjieva, K., Floristic investigation of Quercus cerris and Quercus frainetto communities in Bulgaria. Biotechnology \& Biotechnological Equipment 23 (2009), pp. 314-317.

[64] Kavgac1, A., Čarni, A., Tecimen, B., \& Ozalp, G., Diversity and ecological differentiation of oak forests in NW Thrace (Turkey). Archives of Biological Sciences Belgrade 62 (2010), pp. 705718.

[65] Stupar, V., Milanović, Đ., Brujić, J., \& Čarni, A., Formalized classification and nomenclatural revision of thermophilous deciduous forests
(Quercetalia pubescentis) of Bosnia and Herzegovina. Tuexenia 35 (2015), pp. 85-130.

[66] Lyubenova, M., Tzonev, R., \& Pachedjieva, K., Syntaxonomy of Quercetea pubescentis (Oberd., 1948) Doing Kraft, 1955 in Bulgaria. Comptes rendus de l'Académie bulgare des Sciences, Biologie, Écologie 64 (2011), pp. 565-580.

[67] Stupar, V., Brujić, J., Škvorc, Ž., \& Čarni, A., Vegetation types of thermophilous deciduous forests (Quercetea pubescentis) in the Western Balkans. Phytocoenologia 46 (2016), pp. 49-68.

[68] Košir, P., Čarni, A., \& Di Pietro, R., Classification and phytogeographical differentiation of broadleaved ravine forests in southeastern Europe. Journal of Vegetation Science 19 (2008), pp. 331342.

[69] Fukarek, P., Prilog poznavanju biljnosocioloških odnosa šuma i šibljaka nacionalnog parka Sutjeska. Posebna izdanja ANU BiH, Odjelenje prirodnih $i$ matematičkih nauka 11 (1969), pp. 189-291.

[70] Vukelić, J., Synökologische Charakterisierung und syntaxonomische Einordnung von CarpinionGesellschaften Nordkroatiens. Phytocoenologia 19 (1991), pp. 519-546.

[71] Marinček, L., \& Čarni, A., Die Unterverbände der Hainbuchenwälder des Verbandes ErythronioCarpinion betuli (Horvat 1938) Marinček in Wallnöfer, Mucina et Grass 1993. Scopolia 45 (2000), pp. 1-20.

[72] Matevski, V., Čarni, A., Avramoski, O., Juvan, N., Kostadinovski, M., Košir, P., Marinšek, A., Paušič, A., \& Šilc, U., Forest vegetation of the Galičica mountain range in Macedonia. Založba ZRC, Ljubljana, 2011.

[73] Košir, P., Casavecchia, S., Čarni, A., Škvorc, Ž., Živković, L., \& Biondi, E., Ecological and phytogeographical differentiation of oakhornbeam forests in southeastern Europe. Plant Biosystems 147 (2013), pp. 84-98.

[74] Tzonev, R., Dimitrov, M., Chytrý, M., Roussakova, V. H., Dimova, D., Gussev, C., Pavlov, D., Vulchev, V., Vitkova, A., Gogoushev, G., Nikolov, I., Borisova, D., \& Ganeva, A., Beech forest communities in Bulgaria. Phytocoenologia 36 (2006), pp. 247-279.

[75] Marinšek, A., Šilc, U., \& Čarni, A., Geographical and ecological differentiation of Fagus forest vegetation in SE Europe. Applied Vegetation Science 16 (2013), pp. 131-147.

[76] Willner, W., Jiménez-Alfaro, B., Agrillo, E., Biurrun, I., Campos, J. A., Čarni, A., Casella, L., Csiky, J., Ćušterevska, R., Didukh, Y. P., Ewald, J., Jandt, U., Jansen, F., Kącki, Z., Kavgac1, A., Lenoir, J., Marinšek, A., Onyshchenko, V., Rodwell, J., Schaminée, J., Šibík, J., Škvorc, Ž., Svenning, J.C., Tsiripidis, I., Turtureanu, P.D., Tzonev, 
R., Vassilev, K., Venanzoni, R., Wohlgemuth T., \& Chytrý, M., Classification of European beech forests: a Gordian Knot? Applied Vegetation Science (in press).
[77] Kavgac1, A., Arslan, M., Bingol, U., Erdoğan, N., \& Čarni, A., Classification and phytogeographical differentiation of oriental beech forests in Turkey and Bulgaria. Biologia 67 (2012), pp. 461-473.

\section{ВЕГЕТАЦИЈА НА ЛИСТОПАДНИ ШУМИ НА БАЛКАНСКИОТ ПОЛУОСТРОВ}

\section{Андраж Чарни}

Институт за биологија, Научно истражувачки центар на Словенска академија на науките и уметностите, Љубљана, Словенија Универзитет на Нова Горица, Нова Горица, Словенија Македонска академија на науките и уметностите, Скопје, Република Македонија

Во трудот се дава преглед на листопадните шуми на Балканскиот Полуостров. Претставени се речните, заливните и мочуришните шуми, во кои доминираат Alnus incana, A. glutinosa, Fraxinus excelsior, F. angustifolia, Quercus robur, Salix alba, Ulmus laevis, U. minor; ацидофилни шуми во кои доминираат Betula pendula, Castanea sativa, Fagus sylvatica, Quercus petraea; термофилни шуми во кои доминираат Carpinus orientalis, Ostrya carpinifolia, Quercus cerris, Q. farinetto, Q. petraea, Q. pubescens и мезофилни шуми во кои доминираат Carpinus betulus, Fagus sylvatica, F. orientalis, Fraxinus excelsior, Tilia argentea, T. cordata, T. platyphyllos, Ulmus glabra. Во исто време, шумите се класифицирани во синсистематски стандрадни рамки според Системот на Централна Европа до ниво на сојуз.

Клучни зборови: Балкан; шума; вегетација; класификација 